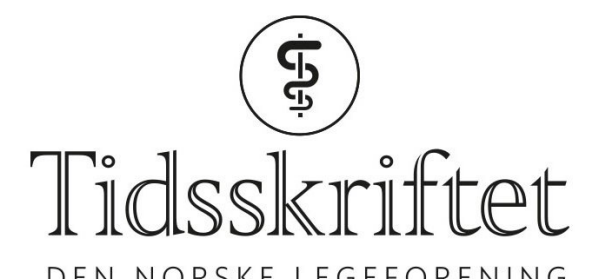

DEN NORSKE LEGEFORENING

\title{
Notis om alkoholforbud i USA
}

TIDLIGERE I TIDSSKRIFTET

JULIE DIDRIKSEN

Tidsskriftet

Perioden fra rundt 1915 og litt utpå 1930-tallet kalles ofte forbudstiden. Et knippe land, deriblant Norge, innførte i denne perioden forbud mot omsetning av alkoholholdige drikkevarer. Forbudene skulle redusere kriminalitet, bedre folkehelsen og løse sosiale problemer. Selv om et av resultatene var at annen kriminalitet, for eksempel smugling, eksploderte, førte det også til at alkoholinntaket sank. Under følger en sak om at forbudet er vedtatt i USA (Tidsskr Nor Lægeforen 1919; 39: 103).

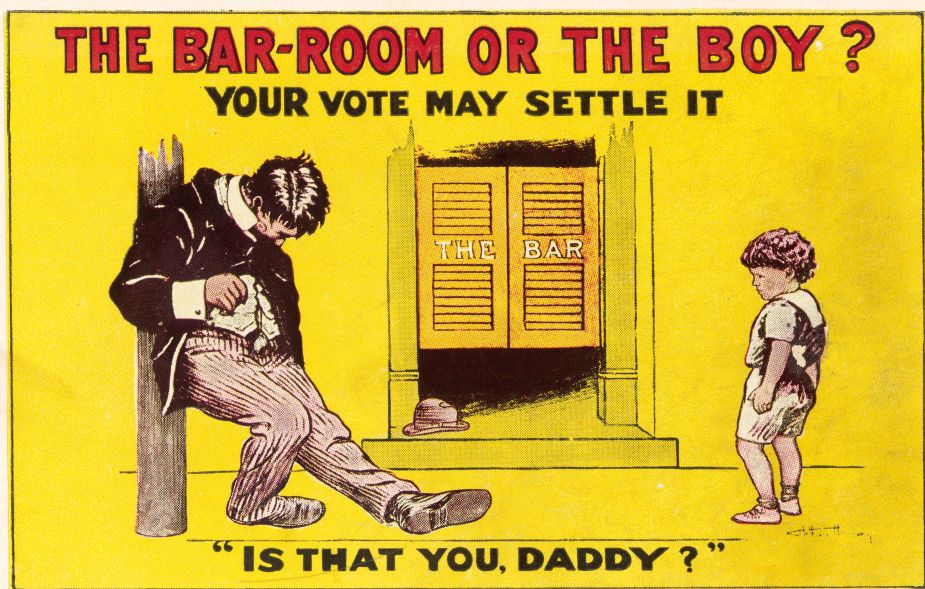

Propaganda for alkoholforbud fra 1918. Illustrasjonsfoto: Rex Shutterstock / NTB Scanpix

\section{Alkoholforbud vedtat for hele Nordamerika.}

Ifølge telegrammer av 17de januar iaar til norske aviser, bl.a. «Morgenbladet», har 36 stater, d.v. s. de nødvendige $3 / 4 \mathrm{i}$ unionen, endelig stadfæstet ændringsforslaget til forbudslov for forbundsforfatningen, som nylig blev fremlagt som lovforslag. Det nationale forbud vil, om det blir vedtat, begynde om et aars tid. Mange mener, at de Forenede Stater vil gjennemføre permanent forbud fra 1ste juli, da krigsforbudsloven, som forbyr fremstilling og salg av spirituøse drikke, med demobiliseringen blir effektiv. Der er allerede igang en bevægelse for at hindre gjennemførelse av den foreslaatte ændringslov. Retten i Kalifornien har fraraadet regjeringen at undertegne ratifikationen med den begrundelse, at statens love kræver, at spørsmaalet skal avgjøres ved folkeavstemning.

Det nationale forbud vil, om det blir vedtat, begynde om et aars tid.

Vi henviser for øvrig til en tidligere meddelelse om denne sak i «Tidsskriftet» for 1916 nr. 3 (s. 
110 o. flg.): «18 tørre stater i Nordamerika.» Siden januar 1916, da der var 18 tørlagte stater, er altsaa dette tal $\emptyset$ ket med det samme antal, sas forbudet nu er vedtat i 36 stater og dermed eo ipso forbud gjennemført for alle de nordamerikanske fristater.

Publisert: 23. mai 2019. Tidsskr Nor Legeforen. DOI: 10.4045/tidsskr.18.0976 (C) Tidsskrift for Den norske legeforening 2020. Lastet ned fra tidsskriftet.no 